\title{
Investigation of the Effects of Salicylic Acid on Some Biochemical Parameters in Zea mays to Glyphosate Herbicide
}

Gulcin Beker Akbulut ${ }^{1}$, Emel Yigit $^{2 \star}$ and Dilek Bayram ${ }^{2}$

${ }^{1}$ Department of Organic Agriculture, Tunceli Vocational School, Tunceli University, Tunceli/Turkey

${ }^{2}$ Department of Biology, Science and Art Faculty, Inonu University, 44280, Malatya/Turkey

\begin{abstract}
In this study, investigated the possible mediatory role of salicylic acid (SA) in protecting Zea mays L. "Martha F1" seedlings from glyphosate toxicity. $0.5 \mathrm{mM}$ SA was treated as preemergence and 17-145 mM glyphosate herbicide was treated postemergence to same groups. The effects upon Peroxidase (POD), Ascorbate Peroxidase (APX), Superoxide Dismutase (SOD), Catalase (CAT) reduced glutathione (GSH), Glutathione Reductase (GR), Glutathione S Transferase (GST), lipid peroxidation, total chlorophyll and total soluble carbohydrate content of this herbicide were investigated on the 1 st, 5 th and 10 th days following the treatment.
\end{abstract}

Keywords: Glyphosate; Salicylic acid; Antioxidant; Lipid peroxidation; Total chlorophyll; Total soluble carbohydrate

\section{Introduction}

Zea mays L. is the most important cereal crop in the World after wheat and rice. While in western countries maize production is highly mechanized, in many other -mainly developing countries - the crop is still grown by smallholders and medium-scale farmers, using traditional and low-input cultivation techniques. Yields under those circumstances are much lower. Besides, maize is an important staple food in developing countries, and a basic ingredient for local drinks and food products. It is also and outstanding feed for livestock, high in energy, low in fiber and easily digestible. As a source of starch, it is major ingredient in industrialized food products [1].

Pesticides are the chemical species that cause death and avoid or reduce growth of plants or animals that are considered as pests. Herbicides are a class of pesticides that are used to kill weeds and other undesirable life forms in agricultural crops [2-4]

Glyphosate is the most extensively used herbicide in the agriculture. Weed management programs in glyphosate resistant field crops have provided highly effective weed control, simplified management decisions, and given cleaner harvested products. However, this systemic herbicide can have extensive unintended effects on nutrient efficiency and disease severity, thereby threatening its agricultural sustainability [5].

Glyphosate acts as a non-selective total herbicide by inhibiting the shikimate pathway responsible for the biosynthesis of aromatic amino acids and phenolic compounds [6], thereby causing impairment of general metabolic processes, such as protein synthesis and photosynthesis [7-9].

When plants are sprayed in crop fields and sub lethal doses of herbicides reach non-target plant species in adjacent habitats through drift, runoff and/or volatilization, resultant effects on sensitive species can be observed in any of four ways: a) Plants at the seedling stage during spray will have their vegetative parts affected, b) the same plants could express the effect through negative impacts on seed production at later stages, c) plants at the reproductive phase during spray have their seed production impacted or d) the vegetative parts of the F1 generation are affected. Therefore, it appears that seedlings and plant species at late vegetative and reproductive stages may be affected differently, and this is most likely influenced in turn by the type of herbicide applied [10].
SA is a common plant-produced phenolic compound and a potential endogenous plant hormone that plays an important role in plant growth and development $[11,12]$. The role of SA is intensively studied in plant responses to biotic stress. In recent years, the involvement of SA in the response to abiotic stresses has come into light [13]. It has been suggested that SA has great agronomic potential to improve the stress tolerance of agriculturally important crops [14,15]. Besides providing disease resistance to the plants, SA could regulate the activities of antioxidant enzymes and increase plant tolerance to abiotic stresses [16,17]. Recent evidence also suggests that SA is an important regulator of photosynthesis because it affects leaf and chloroplast structure $[18,19]$.

In indirect stress perception ROS are components frequently used as signalling molecules. However, ROS themselves can be subject to direct or indirect perception mechanisms [20]. Under normal growth conditions, ROS are inevitably generated in cellular compartments during oxygen metabolism, but antioxidative systems control the level of ROS. Efficient defense system enzymatic antioxidant: POD, APX, SOD, CAT, GR and GST and also non-enzymatic antioxidants: ascorbate, GSH etc. may regulate ROS level directly or indirectly and thus, the antioxidants are an indicative of level of tolerance in plants [21]. In stress condition, the balance between the productions of ROS and antioxidants get disturbed and thus, level of ROS is enhanced to an extent that causes severe damage to the biomolecules [22,23]. ROS directly react with biomolecules cause lipid peroxidation, protein oxidation and DNA mutation [24,25].

This work was to show the changes of the antioxidant system in response to glyphosate herbicide and the effect of SA pretreatment on maize. The antioxidant status was investigated through analyzing changes in POD, APX, SOD, CAT, GSH, GR, GST changes and

*Corresponding author: Emel Yıgıt, Inonu University, Science and Art Faculty, Department of Biology, 44280, Malatya/Turkey, Tel: +90 422 3773763; Fax: +90 422 3410037; E-mail: emel-yigit@windowslive.com

Received December 23, 2014; Accepted January 01, 2015; Published January 31,2015

Citation: Akbulut GB, Yigit E, Bayram D (2015) Investigation of the Effects of Salicylic Acid on Some Biochemical Parameters in Zea mays to Glyphosate Herbicide. J Environ Anal Toxicol 5: 271. doi:10.4172/2161-0525.1000271

Copyright: @ 2015 Akbulut GB, et al. This is an open-access article distributed under the terms of the Creative Commons Attribution License, which permits unrestricted use, distribution, and reproduction in any medium, provided the original author and source are credited. 
Citation: Akbulut GB, Yigit E, Bayram D (2015) Investigation of the Effects of Salicylic Acid on Some Biochemical Parameters in Zea mays to Glyphosate Herbicide. J Environ Anal Toxicol 5: 271. doi:10.4172/2161-0525.1000271

determining the lipid peroxidation level. Besides, in this study, total chlorophyll and total carbohydrate content in Z. mays were determined. In addition, this work was to provide evidence for SA protective interference action and regulation of oxidative stress caused by glyphosate toxicity in maize.

\section{Materials and Methods}

\section{Preparation of the plant samples}

In the present study, the glyphosate herbicide was provided from Sygenta Company and Z. mays L. cv. "Martha F1" seeds were provided from May Seed Company. The samples were grown in perlitecontaining pots by using Hoagland's solution [26]. The tests were conducted in a climate room with a temperature of $23 \pm 2{ }^{\circ} \mathrm{C}$ and a humidity of $60 \%$. Samples were planted after a portion of the plants was kept for six hours in distillated water and another portion was kept for six hours in $0.5 \mathrm{mM} \mathrm{SA}$ solution. On the $21^{\text {st }}$ day of the growth, postemergence glyphosate was applied to corn plants of appropriate size by spraying in doses of $17,23,30,39,51,66,85,111$ and $145 \mathrm{mM}$. The leaf samples were extracted from the treatment groups on the $1^{\text {st }}, 5^{\text {th }}$ and $10^{\text {th }}$ days and subjected to analyses.

In the preliminary trials performed with solutions in different concentrations prepared by taking the application dose of glyphosate to the terrain into consideration, the toxic doses were determined for corn and the upper and lower concentrations of this dose was applied to corn by considering the possible residue in the soil depending on the half life of herbicide. In the evaluation after preliminary trials it was observed that SA response is better in $0.5 \mathrm{mM}$ concentration concerning stress response.

\section{Determination of POD}

POD activity was performed by following the methods of Peters et al. [27]. Enzyme activity was measured at $436 \mathrm{~nm}$ according to $\mathrm{Mac}$ Adam et al. [28].

\section{Determination of APX}

APX activity was performed by following the methods of Nakano and Asada [29] and Cakmak [30]. The enzyme activity was defined as the alteration in absorbance per minute at $290 \mathrm{~nm}$. APX activity was calculated by using the extinction coefficient of $2.8 \mathrm{mM}-1 \mathrm{~cm}-1$.

\section{Determination of SOD}

SOD activity was assayed by measuring its ability to inhibit the photochemical reduction of Nitro Blue Tetrazolium (NBT) according to the method of McCord and Fridovich [31]. One unit of the enzyme activity was defined as the amount of enzyme required to result in a $50 \%$ inhibition of the reduction rate of NBT under assay conditions.

\section{Determination of CAT}

CAT activity was measured according to the method of Luck by measuring the decrease of absorbance at $240 \mathrm{~nm}$ because of $\mathrm{H}_{2} \mathrm{O}_{2}$ decomposition. One unit of enzyme activity was defined as the amount of the enzyme that decreased $1 \mu \mathrm{mol} \mathrm{H}_{2} \mathrm{O}_{2} \min ^{-1}$ [32].

\section{Determination of GST}

GST activity was assayed according to the method of Habig et al. [33] with 1-Chloro-2,4-DiNitroBenzene (CDNB) as substrate. Enzyme activity was determined by monitoring changes in absorbance at 340 $\mathrm{nm}$, which is related to the rate of CDNB conjugation with GSH.

\section{Determination of GR}

GR activity was assayed by the method of Cribb et al. [34]. The reaction was initiated by the addition of the GSSG to the cuvette, and the decrease in absorbance at $405 \mathrm{~nm}$ was examined at $30^{\circ} \mathrm{C}$ for $1 \mathrm{~min}$ with UV spectrophotometry. A unit of GR activity is defined as the amount of the enzyme catalyzing the reduction of $1 \mu \mathrm{M}$ of NADPH per min.

\section{Determination of GSH}

Glutathione amount was measured according to the method by Akerboom and Sies [35]. GSH concentration was estimated from a standart curve and reported as $\mu \mathrm{mol} \mathrm{GSH} / \mathrm{mg}$ protein.

\section{Determination of Lipid peroxidation}

The method was performed by following Heath and Packer [36]. Absorbance of the supernatant was measured at $532 \mathrm{~nm}$ and $600 \mathrm{~nm}$ and MDA content was calculated using an extinction coefficient of 155 $\mathrm{mM}-1 \mathrm{~cm}-1$ by subtracting the absorbance at $532 \mathrm{~nm}$ from that at 600 nm.

\section{Determination of total chlorophyll}

De Kok and Graham's method [37] was employed in pigment extraction. Absorbance values of the centrifuged samples were read according to Lichtenthaler and Welburn [38] at 662, 645 and $470 \mathrm{~nm}$.

\section{Determination of soluble carbohydrate content}

The content of total soluble carbohydrate was measured according to the method recommended by Rosenberg using glucose as a standard at $620 \mathrm{~nm}$ [39].

\section{Determination of total soluble protein}

We determined the total soluble protein content as previously described by Bradford [40] using BSA as a standard. We spectrophotometrically measured reactions at $290 \mathrm{~nm}$.

\section{Statistical analysis}

Statistical analysis was performed using SPSS 15.0 software. Duncan's test [41] was used for significance control $(p<0.05)$ following variance analysis.

\section{Results}

\section{Enyzme activities}

POD activity was highest on the $1^{\text {st }}$ day in $66 \mathrm{mM}$ glyphosate applied group, on the $5^{\text {th }}$ day and $10^{\text {th }}$ day in $111 \mathrm{mM}$ glyphosate applied group. The lowest POD activity was measured in control group on the $1^{\text {st }}, 5^{\text {th }}$ and $10^{\text {th }}$ days. POD activity increased on the $5^{\text {th }}$ and $10^{\text {th }}$ days depending on days. These changes were statistically significant $(\mathrm{p}<0.05)$ (Table 1$)$.

It was determined that the lowest APX and SOD activity were observed in control group on the $1^{\text {st }}, 5^{\text {th }}$ and $10^{\text {th }}$ days. APX and SOD activity increased as the number of days increases (Tables 2 and 3). We statistically determined that CAT activity increased on the $5^{\text {th }}$ and reduced on the $10^{\text {th }}$ days together with concentration increase (Table $4)$.

The lowest GSH content on the $1^{\text {st }}$ day was determined in control group. There was an increase in GSH content together with increasing glyphosate concentration. GSH content increased on the $5^{\text {th }}$ and $10^{\text {th }}$ days in 17-66 $\mathrm{mM}$ glyphosate applied groups and decreased on the $10^{\text {th }}$ 
Citation: Akbulut GB, Yigit E, Bayram D (2015) Investigation of the Effects of Salicylic Acid on Some Biochemical Parameters in Zea mays to Glyphosate Herbicide. J Environ Anal Toxicol 5: 271. doi:10.4172/2161-0525.1000271

Page 3 of 9

day in $85-145 \mathrm{mM}$ glyphosate applied groups (Table 5). The GR activity increased on the $5^{\text {th }}$ day while decreased on the $10^{\text {th }}$ day. The highest GR activity was determined on the $5^{\text {th }}$ day in $145 \mathrm{mM}$ glyphosate applied group as $0.492 \mu / \mathrm{mg}$ protein (Table 6 ). The highest activity of GST was determined on the $10^{\text {th }}$ day in $145 \mathrm{mM}$ glyphosate applied group. These changes were statistically significant (Table 7).

\section{MDA content}

The MDA content increased compared to control group. MDA content also increased on the $5^{\text {th }}$ and $10^{\text {th }}$ days compared to $1^{\text {st }}$ day in the SA-treated plants. The highest MDA content was determined as $7.00 \mu \mathrm{mol} \mathrm{MDA} / \mathrm{g} \mathrm{FW}$ in $66 \mathrm{mM}$ glyphosate applied group on the $1^{\text {st }}$ day, $9.58 \mu \mathrm{mol} \mathrm{MDA} / \mathrm{g} \mathrm{FW}$ in $85 \mathrm{mM}$ glyphosate applied group on the $5^{\text {th }}$ day and $14.31 \mu \mathrm{mol} \mathrm{MDA} / \mathrm{g} \mathrm{FW}$ in $145 \mathrm{M}$ glyphosate applied group on the $10^{\text {th }}$ day (Table 8 )

\section{Total chlorophyll}

The highest total chlorophyll content was determined in control group on the $1^{\text {st }}, 5^{\text {th }}$ and $10^{\text {th }}$ days. The lowest total chlorophyll content was determined as $11.41 \mu \mathrm{g} / \mathrm{g}$ in $145 \mathrm{mM}$ glyphosate applied group on the $1^{\text {st }}$ day, $9.73 \mu \mathrm{g} / \mathrm{g}$ in $66 \mathrm{mM}$ glyphosate applied group on the $5^{\text {th }}$ day and $9.62 \mu \mathrm{g} / \mathrm{g}$ in $145 \mathrm{mM}$ glyphosate applied group on the $10^{\text {th }}$ day. We statistically determined that total chlorophyll content reduced on the $5^{\text {th }}$ and $10^{\text {th }}$ days (Table 9).

\section{Total soluble carbohydrate}

The highest total soluble carbohydrate content was determined in control group on the $1^{\text {st }}, 5^{\text {th }}$ and $10^{\text {th }}$ days. The total soluble carbohydrate content decreased depending to increasing concentrations on the $5^{\text {th }}$ and $10^{\text {th }}$ days. The lowest total soluble carbohydrate content was determined as $0.43 \mu \mathrm{g} / \mathrm{g}$ in $145 \mathrm{mM}$ glyphosate applied group on the $1^{\text {st }}$ day, $0.24 \mu \mathrm{g} / \mathrm{g}$ in $111 \mathrm{mM}$ glyphosate applied group on the $5^{\text {th }}$ day and $0.18 \mu \mathrm{g} / \mathrm{g}$ in $145 \mathrm{mM}$ glyphosate applied group on the $10^{\text {th }}$ day. These changes were statistically significant $(\mathrm{p}<0.05)($ Table 10$)$.

\section{Discussion}

Glyphosate is commonly used in agriculture, forestry, and nurseries for the control or destruction of herbaceous plants [42]. Plants have evolved various protective strategies to minimize the herbicide toxicity. One of the protective mechanisms is the antioxidant system [43]. SA is used for regulation of oxidative stress in plants subjected to unfavorable environmental conditions [44]. The present study explores the effect of SA on $Z$. mays under glyphosate stress.

Adverse effects after coffee exposure to glyphosate have been shown both as damage $[45,46]$ and as a reduction in plant nutrient concentration [47] after a glyphosate spray drift simulation [48].

POD activity in plant tissues has been used as a biomarker for various contaminant stresses [49-51]. POD upregulation after herbicide exposure has been demonstrated in wheat [52], tobacco [53] and many other plant species. Basantani et al. reported that CAT activity found to increase after glyphosate treatment in the two $\mathrm{V}$. radiata varieties. There was 2.7 fold increase in activity at $4 \mathrm{mM}$ as compared to control in PDM11, and 1.7-fold in PDM54 [54] In other researchs related to SA determined that SA, a signal molecule, modified the antioxidative system by inhibiting CAT and stimulating POD enzymes [44,55]. It has been shown that exogenous SA application resulted in the alleviation of Cd-induced ROS overproduction in Arabidopsis thaliana [56] and maize seedlings [44]. Belkadhi et al. reported that the Cd-treated plantlets presoaked with SA exhibited less lipid and protein oxidation and membrane alteration, as well as a high level of total antioxidant capacities and increased activities of antioxidant enzymes except of CAT. They suggested that SA plays an important role in triggering the root antioxidant system, thereby preventing membrane damage as well as the denaturation of its components [57]. In this study, we found that in SA-treated plants, POD activity was increased in all treatment groups but CAT activity was decreased on the $10^{\text {th }}$ day (Tables 1 and 4 ). In the SA-pre-treated plants, the reason of the increase in POD activity may be related to the induction of stress resistance by SA. In the SApre-treated plants the decrease in CAT activity may be related to the SA-mediated mechanism underlying the accumulation of $\mathrm{H}_{2} \mathrm{O}_{2}$.

APX appears to play an essential role in the scavenging process when they coordinate with SOD [58]. Jiang and Yang (2009) reported that APX activity increased during the exposure to prometryne [22] After treated with silicon, there was an increase of APX activity in saltstressed cucumbers [59]. These results were supported our data, which indicate that APX activity increase during the exposure to glyphosate (Table 2). In this study the SOD activity increased in the treatment groups compared to control groups (Table 3 ). The reason of this increase in the APX and SOD activity may be related to the antioxidant characteristics of SA.

POD

(U/mg protein)

\begin{tabular}{|c|c|c|c|}
\hline $\begin{array}{c}0.5 \text { mM SA+ } \\
\text { Glyphosate (mM) }\end{array}$ & & & \\
\hline & 1st day & 5th day & 10th day \\
\hline Control & A3.95 $\pm 0.03 e$ & A3.95 $\pm 0.02 f$ & A3.98 $\pm 0.01 \mathrm{~h}$ \\
\hline 17 & $\mathrm{C} 4.16 \pm 0.03 \mathrm{de}$ & B4.71 $\pm 0.07 e$ & A5.35 $\pm 0.17 \mathrm{~g}$ \\
\hline 23 & $\mathrm{C} 4.16 \pm 0.05 \mathrm{de}$ & $B 5.20 \pm 0.07 d$ & $A 6.45 \pm 0.21 f$ \\
\hline 30 & $\mathrm{C} 4.39 \pm 0.03 \mathrm{~cd}$ & $B 4.74 \pm 0.08 e$ & $\mathrm{~A} 6.92 \pm 0.01 \mathrm{e}$ \\
\hline 39 & $\mathrm{C} 4.37 \pm 0.09 \mathrm{~cd}$ & B5.71 $\pm 0,13 \mathrm{c}$ & $\mathrm{A} 7.21 \pm 0.05 \mathrm{e}$ \\
\hline 51 & $\mathrm{C} 5.03 \pm 0.25 \mathrm{a}$ & $B 6.33 \pm 0.23 b$ & $A 8.70 \pm 0.36 d$ \\
\hline 66 & C5.17 $\pm 0.03 a$ & $B 7.04 \pm 0.04 a$ & $\mathrm{~A} 10.08 \pm 0.14 \mathrm{c}$ \\
\hline 85 & $\mathrm{C} 4.95 \pm 0.03 a$ & $B 6.95 \pm 0.02 a$ & $A 11.32 \pm 0.09 b$ \\
\hline 111 & $\mathrm{C} 4.84 \pm 0.04 \mathrm{ab}$ & $\mathrm{B} 7.15 \pm 0.06 \mathrm{a}$ & $\mathrm{A} 11.82 \pm 0.1 \mathrm{a}$ \\
\hline 145 & $\mathrm{C} 4.53 \pm 0.16 \mathrm{bc}$ & $B 6.19 \pm 0.09 b$ & $A 11.35 \pm 0.07 b$ \\
\hline
\end{tabular}

Table 1: Changes in POD activity in Zea mays leaves. The different lower case letters indicate significant differences ( $p<0.05)$ among the different concentrations of glyphosate according to Duncan's tests. The different upper case letters indicate significant differences $(p<0.05)$ for each concentration of glyphosate according to independent samples $t$ tests 
Citation: Akbulut GB, Yigit E, Bayram D (2015) Investigation of the Effects of Salicylic Acid on Some Biochemical Parameters in Zea mays to Glyphosate Herbicide. J Environ Anal Toxicol 5: 271. doi:10.4172/2161-0525.1000271

Page 4 of 9

APX

(U/mg protein)

\begin{tabular}{|c|c|c|c|}
\hline \multicolumn{4}{|c|}{$\begin{array}{c}0.5 \text { mM SA+ } \\
\text { Glyphosate (mM) }\end{array}$} \\
\hline & 1st day & 5th day & 10th day \\
\hline Control & $A 0.85 \pm 0.01 d$ & $\mathrm{~A} 0.91 \pm 0.01 \mathrm{e}$ & $A 0.89 \pm 0.01 d$ \\
\hline 17 & $\mathrm{C} 0.94 \pm 0.02 \mathrm{bc}$ & B1.14 $\pm 0.01 d$ & A1.58 $\pm 0.01 \mathrm{c}$ \\
\hline 23 & $\mathrm{C} 0.99 \pm 0.01 \mathrm{~b}$ & B1.34 $\pm 0.01 \mathrm{c}$ & $A 2.08 \pm 0.04 b$ \\
\hline 30 & $\mathrm{C} 0.97 \pm 0.01 \mathrm{bc}$ & B1.14 $\pm 0.05 d$ & $A 2.60 \pm 0.23 a$ \\
\hline 39 & $\mathrm{C} 0.92 \pm 0.03 \mathrm{~cd}$ & $\mathrm{~B} 1.57 \pm 0.06 \mathrm{a}$ & $\mathrm{A} 2.11 \pm 0.11 \mathrm{~b}$ \\
\hline 51 & $\mathrm{C} 0.90 \pm 0.01 \mathrm{~cd}$ & B1. $50 \pm 0.04 a b$ & $A 1.94 \pm 0.03 b$ \\
\hline 66 & $\mathrm{C} 0.95 \pm 0.04 \mathrm{bc}$ & $\mathrm{B} 1.31 \pm 0.04 \mathrm{c}$ & $\mathrm{A} 2.00 \pm 0.06 \mathrm{~b}$ \\
\hline 85 & $C 1.10 \pm 0.03 a$ & B1. $49 \pm 0.04 a b$ & $A 1.88 \pm 0.01 b$ \\
\hline 111 & $C 1.10 \pm 0.01 a$ & B1. $38 \pm 0.09 \mathrm{bc}$ & $\mathrm{A} 2.62 \pm 0.09 \mathrm{a}$ \\
\hline 145 & $\mathrm{C} 1.11 \pm 0.02 \mathrm{a}$ & B1.32 $\pm 0.01 \mathrm{C}$ & $\mathrm{A} 2.88 \pm 0.06 \mathrm{a}$ \\
\hline
\end{tabular}

Table 2: Changes in APX activity in Z. mays leaves. The different lower case letters indicate significant differences $(p<0.05)$ among the different concentrations of glyphosate according to Duncan's tests. The different upper case letters indicate significant differences $(p<0.05)$ for each concentration of glyphosate according to independent samples $t$ tests

SOD

(U/mg protein)

\begin{tabular}{|c|c|c|c|}
\hline \multicolumn{4}{|l|}{$\begin{array}{c}0.5 \text { mM SA+ } \\
\text { Glyphosate (mM) }\end{array}$} \\
\hline & 1st day & 5th day & 10th day \\
\hline Control & A3.17 $\pm 0.01 \mathrm{~g}$ & $A 3.16 \pm 0.03 i$ & A3.17 $\pm 0.01 j$ \\
\hline 17 & B3.25 $\pm 0.02 f g$ & A3.74 $\pm 0.01 \mathrm{~h}$ & $A 3.70 \pm 0.01 i$ \\
\hline 23 & C3.28 $\pm 0.01 f$ & B3.91 $\pm 0.01 \mathrm{~g}$ & $\mathrm{~A} 4.13 \pm 0.02 \mathrm{~h}$ \\
\hline 30 & C3.47 $\pm 0.02 \mathrm{e}$ & $B 4.15 \pm 0.02 f$ & $\mathrm{~A} 4.63 \pm 0.0 \mathrm{~g}$ \\
\hline 39 & C3.82 $\pm 0.07 d$ & B4.32 $\pm 0.01 \mathrm{e}$ & $A 5.12 \pm 0.01 f$ \\
\hline 51 & $\mathrm{C} 3.86 \pm 0.01 \mathrm{~d}$ & $B 4.42 \pm 0.01 d$ & A5.29 $\pm 0.01 \mathrm{e}$ \\
\hline 66 & $C 4.05 \pm 0.03 b$ & $\mathrm{~B} 4.68 \pm 0.01 \mathrm{c}$ & $A 5.68 \pm 0.01 d$ \\
\hline 85 & C3.96 $\pm 0.01 \mathrm{c}$ & B4.71 $\pm 0.04 \mathrm{C}$ & $A 6.07 \pm 0.03 c$ \\
\hline 111 & $\mathrm{C} 4.13 \pm 0.01 \mathrm{ab}$ & B5.21 $\pm 0.01 b$ & $A 6.49 \pm 0.02 b$ \\
\hline 145 & $C 4.19 \pm 0.01 b$ & B5.30 $\pm 0.01 a$ & $A 7.11 \pm 0.01 a$ \\
\hline
\end{tabular}

Table 3: Changes in SOD activity in $Z$. mays leaves. The different lower case letters indicate significant differences $(p<0.05)$ among the different concentrations of glyphosate according to Duncan's tests. The different upper case letters indicate significant differences $(p<0.05)$ for each concentration of glyphosate according to independent samples $t$ tests

\begin{tabular}{|c|c|c|c|}
\hline \multicolumn{4}{|c|}{$\begin{array}{c}\text { CAT } \\
\text { (U/mg protein) }\end{array}$} \\
\hline \multicolumn{4}{|l|}{$\begin{array}{c}0.5 \text { mM SA+ } \\
\text { Glyphosate (mM) }\end{array}$} \\
\hline & 1st day & 5th day & 10th day \\
\hline Control & A3.50 $\pm 0.03 e$ & A3.52 $\pm 0.01 \mathrm{~g}$ & $A 3.50 \pm 0.01 f$ \\
\hline 17 & C $3.64 \pm 0.02 b c$ & A3.92 $\pm 0.01 f$ & B3.29 $\pm 0.03 e$ \\
\hline 23 & $\mathrm{C} 3.59 \pm 0.01 \mathrm{~cd}$ & $\mathrm{~A} 4.13 \pm 0.01 \mathrm{e}$ & $B 381 \pm 0.03 d$ \\
\hline 30 & C3.51 $\pm 0.02 \mathrm{e}$ & $A 4.30 \pm 0.01 d$ & B4.09 $\pm 0.04 \mathrm{C}$ \\
\hline 39 & C3.44 $\pm 0.01 f$ & $A 4.28 \pm 0.01 d$ & B4.08 $\pm 0.01 \mathrm{C}$ \\
\hline 51 & C3.53 $\pm 0.01 \mathrm{de}$ & $\mathrm{A} 4.56 \pm 0.01 \mathrm{c}$ & B $4.02 \pm 0.01 \mathrm{C}$ \\
\hline 66 & C3.53 $\pm 0.01 \mathrm{de}$ & $A 4.82 \pm 0.03 b$ & B4.01 $\pm 0.03 c$ \\
\hline 85 & C3.68 $\pm 0.01 b$ & $\mathrm{~A} 4.90 \pm 0.01 \mathrm{a}$ & B4.21 $\pm 0.04 b$ \\
\hline 111 & C3.81 $\pm 0.03 a$ & $\mathrm{~A} 4.89 \pm 0.01 \mathrm{a}$ & $B 4.24 \pm 0.02 b$ \\
\hline 145 & C3.78 $\pm 0.02 a$ & $\mathrm{~A} 4.91 \pm 0.01 \mathrm{a}$ & B4.47 $\pm 0.01 a$ \\
\hline
\end{tabular}

Table 4: Changes in CAT activity in Z. mays leaves. The different lower case letters indicate significant differences ( $<<0.05)$ among the different concentrations of glyphosate according to Duncan's tests. The different upper case letters indicate significant differences $(p<0.05)$ for each concentration of glyphosate according to independent samples $t$ tests 
Citation: Akbulut GB, Yigit E, Bayram D (2015) Investigation of the Effects of Salicylic Acid on Some Biochemical Parameters in Zea mays to Glyphosate Herbicide. J Environ Anal Toxicol 5: 271. doi:10.4172/2161-0525.1000271

Page 5 of 9

GSH (U/mg protein)

\begin{tabular}{|c|c|c|c|}
\hline \multicolumn{4}{|c|}{ GSH (U/mg protein) } \\
\hline \multicolumn{4}{|l|}{$\begin{array}{c}0.5 \text { mM SA+ } \\
\text { Glyphosate (mM) }\end{array}$} \\
\hline & 1st day & 5th day & 10th day \\
\hline Control & A $1.91 \pm 0.01 \mathrm{e}$ & $A 1.90 \pm 0.01 \mathrm{i}$ & $A 1.89 \pm 0.01 f$ \\
\hline 17 & $\mathrm{C} 1.96 \pm 0.03 \mathrm{e}$ & B2.29 $\pm 0.05 h$ & $\mathrm{~A} 2.98 \pm 0.01 \mathrm{e}$ \\
\hline 23 & $\mathrm{C} 1.99 \pm 0.01 \mathrm{e}$ & $B 2.79 \pm 0.19 \mathrm{~g}$ & $A 3.79 \pm 0.01 d$ \\
\hline 30 & $C 2.17 \pm 0.09 d$ & B3.23 $\pm 0.10 f$ & A3.96 $\pm 0.03 d$ \\
\hline 39 & $\mathrm{C} 2.30 \pm 0.01 \mathrm{bc}$ & B3.67 $\pm 0.17 e$ & A $4.37 \pm 0.35 c$ \\
\hline 51 & $\mathrm{C} 2.27 \pm 0.02 \mathrm{~cd}$ & B4.10 $\pm 0.02 d$ & $A 5.10 \pm 0.05 b$ \\
\hline 66 & $\mathrm{C} 2.38 \pm 0.03 \mathrm{abc}$ & B4.72 $\pm 0.19 \mathrm{c}$ & A5.25 $\pm 0.10 a b$ \\
\hline 85 & $\mathrm{C} 2.41 \pm 0.02 \mathrm{ab}$ & $A 6.21 \pm 0.06 b$ & $B 5.52 \pm 0.07 a$ \\
\hline 111 & $\mathrm{C} 2.45 \pm 0.02 \mathrm{a}$ & $A 6.95 \pm 0.01 a$ & B5.31 $\pm 0.02 \mathrm{ab}$ \\
\hline 145 & $\mathrm{C} 2.31 \pm 0.01 \mathrm{bc}$ & $\mathrm{A} 6.86 \pm 0.03 \mathrm{a}$ & $B 4.56 \pm 0.06 \mathrm{c}$ \\
\hline
\end{tabular}

Table 5: Changes in GSH content in Z. mays leaves. The different lower case letters indicate significant differences $(p<0.05)$ among the different concentrations of glyphosate according to Duncan's tests. The different upper case letters indicate significant differences $(p<0.05)$ for each concentration of glyphosate according to independent samples $t$ tests

\begin{tabular}{|c|c|c|c|}
\hline \multicolumn{4}{|c|}{ GR (U/mg protein) } \\
\hline \multicolumn{4}{|l|}{$\begin{array}{c}0.5 \text { mM SA+ } \\
\text { Glyphosate (mM) }\end{array}$} \\
\hline & 1st day & 5th day & 10th day \\
\hline Control & $A 0.095 \pm 0.0018 d$ & $A 0.093 \pm 0.0006 f$ & $A 0.093 \pm 0.0003 f$ \\
\hline 17 & $C 0.105 \pm 0.0025 c$ & $A 0.369 \pm 0.0129 e$ & $\mathrm{~B} 0.218 \pm 0.0040 \mathrm{e}$ \\
\hline 23 & $C 0.115 \pm 0.0023 b$ & $A 0.427 \pm 0.0157 d$ & B0.251 $\pm 0.0191 \mathrm{~cd}$ \\
\hline 30 & $\mathrm{C} 0.120 \pm 0.0018 \mathrm{~b}$ & $A 0.412 \pm 0.0055 d$ & B $0.263 \pm 0.0068 \mathrm{bc}$ \\
\hline 39 & $\mathrm{C} 0.115 \pm 0.0040 \mathrm{~b}$ & $\mathrm{~A} 0.475 \pm 0.0071 \mathrm{ab}$ & B0.293 $\pm 0.0051 \mathrm{a}$ \\
\hline 51 & $\mathrm{C} 0.122 \pm 0.0016 \mathrm{~b}$ & $\mathrm{~A} 0.483 \pm 0.0036 \mathrm{a}$ & B0.275 $\pm 0.0009 a b$ \\
\hline 66 & $\mathrm{C} 0.120 \pm 0.0010 \mathrm{~b}$ & $\mathrm{~A} 0.456 \pm 0.0121 \mathrm{bc}$ & B0.235 $\pm 0.004 \mathrm{de}$ \\
\hline 85 & $\mathrm{C} 0.131 \pm 0.0006 \mathrm{~b}$ & A $0.437 \pm 0.0087 \mathrm{~cd}$ & B0.243 $\pm 0.0015 \mathrm{~cd}$ \\
\hline 111 & $\mathrm{C} 0.128 \pm 0.0015 \mathrm{a}$ & $\mathrm{A} 0.491 \pm 0.0007 \mathrm{a}$ & B0.263 $\pm 0.0003 \mathrm{bc}$ \\
\hline 145 & $\mathrm{C} 0.117 \pm 0.0003 a$ & $A 0.492 \pm 0.0012 a$ & B $0.261 \pm 0.0072 b c$ \\
\hline
\end{tabular}

Table 6: Changes in GR activity in Z. mays leaves. The different lower case letters indicate significant differences $(p<0.05)$ among the different concentrations of glyphosate according to Duncan's tests. The different upper case letters indicate significant differences $(p<0.05)$ for each concentration of glyphosate according to independent samples $t$ tests

\begin{tabular}{|c|c|c|c|}
\hline \multicolumn{4}{|c|}{ GST (U/mg protein) } \\
\hline \multicolumn{4}{|l|}{$\begin{array}{c}0.5 \text { mM SA+ } \\
\text { Glyphosate (mM) }\end{array}$} \\
\hline & 1st day & 5th day & 10th day \\
\hline Control & $A 0.088 \pm 0.01 d$ & $A 0.090 \pm 0.01 \mathrm{~h}$ & $A 0.090 \pm 0.01 f$ \\
\hline 17 & B0.098 $\pm 0.01 b c$ & $B 0.100 \pm 0.01 \mathrm{~g}$ & $\mathrm{~A} 0.133 \pm 0.01 \mathrm{e}$ \\
\hline 23 & $\mathrm{C} 0.118 \pm 0.08 \mathrm{a}$ & B0.147 $\pm 0.01 f$ & $A 0.283 \pm 0.03 d$ \\
\hline 30 & $C 0.105 \pm 0.01 b$ & B0.153 $\pm 0.01 \mathrm{e}$ & $A 0.392 \pm 0.01 b c$ \\
\hline 39 & $\mathrm{C} 0.093 \pm 0.01 \mathrm{~cd}$ & B0.175 $\pm 0.01 \mathrm{c}$ & $A 0.396 \pm 0.03 b c$ \\
\hline 51 & $\mathrm{C} 0.096 \pm 0.01 \mathrm{bcd}$ & B0.169 $\pm 0.01 d$ & $A 0.397 \pm 0.01 b c$ \\
\hline 66 & $\mathrm{C} 0.103 \pm 0.01 \mathrm{bc}$ & B0.168 $\pm 0.01 d$ & $A 0.380 \pm 0.03 c$ \\
\hline 85 & $\mathrm{C} 0.096 \pm 0.01 \mathrm{bcd}$ & B0.167 $\pm 0.01 d$ & $A 0.418 \pm 0.03 b$ \\
\hline 111 & $\mathrm{C} 0.114 \pm 0.02 \mathrm{a}$ & B0.320 $\pm 0.02 b$ & $\mathrm{~A} 0.472 \pm 0.03 \mathrm{a}$ \\
\hline 145 & $\mathrm{C} 0.115 \pm 0.01 \mathrm{a}$ & B0.346 $\pm 0.01 \mathrm{a}$ & $\mathrm{A} 0.458 \pm 0.01 \mathrm{a}$ \\
\hline
\end{tabular}

Table 7: Changes in GST activity in Z. mays leaves. The different lower case letters indicate significant differences ( $p<0.05$ ) among the different concentrations of glyphosate according to Duncan's tests. The different upper case letters indicate significant differences $(p<0.05)$ for each concentration of glyphosate according to independent samples $t$ tests 
Citation: Akbulut GB, Yigit E, Bayram D (2015) Investigation of the Effects of Salicylic Acid on Some Biochemical Parameters in Zea mays to Glyphosate Herbicide. J Environ Anal Toxicol 5: 271. doi:10.4172/2161-0525.1000271

Page 6 of 9

\section{MDA ( $\mu \mathrm{mol}$ MDA/g fresh weight)}

$0.5 \mathrm{mM} \mathrm{SA}+$

Glyphosate (mM)

\begin{tabular}{|c|c|c|c|}
\hline & 1st day & 5th day & 10th day \\
\hline Control & $A 5.82 \pm 0.04 f$ & A5.83 $\pm 0.03 h$ & $A 5.81 \pm 0.03 i$ \\
\hline 17 & $C 5.83 \pm 0.03 f$ & B6.02 $\pm 0.01 \mathrm{~h}$ & A7.21 $\pm 0.01 \mathrm{~h}$ \\
\hline 23 & C6.11 $0.06 \mathrm{e}$ & $B 7.02 \pm 0.01 \mathrm{~g}$ & A7.58 $\pm 0.22 \mathrm{~g}$ \\
\hline 30 & C6.13 $0.02 e$ & $B 7.51 \pm 0.03 f$ & $\mathrm{~A} 10.00 \pm 0.07 f$ \\
\hline 39 & C6.33 $\pm 0.06 d$ & $\mathrm{~B} 7.76 \pm 0.10 \mathrm{e}$ & $\mathrm{A} 10.45 \pm 0.06 \mathrm{e}$ \\
\hline 51 & C6.96 $\pm 0.04 a b$ & $B 8.57 \pm 0.01 d$ & $\mathrm{~A} 11.38 \pm 0.01 \mathrm{~d}$ \\
\hline 66 & $\mathrm{C} 7.00 \pm 0.01 \mathrm{a}$ & B9.18 $\pm 0.02 b$ & $A 12.29 \pm 0.03 c$ \\
\hline 85 & $\mathrm{C} 6.84 \pm 0.08 \mathrm{~b}$ & B9.58 $\pm 0.17 a$ & $A 12.70 \pm 0.04 b$ \\
\hline 111 & $\mathrm{C} 6.67 \pm 0.04 \mathrm{c}$ & B8.91 $\pm 0.07 \mathrm{c}$ & $A 12.90 \pm 0.01 b$ \\
\hline 145 & $C 6.41 \pm 0.06 d$ & B8.84 $\pm 0.07 c$ & $\mathrm{~A} 14.31 \pm 0.13 a$ \\
\hline
\end{tabular}

Table 8: Changes in MDA content in Z. mays leaves. The different lower case letters indicate significant differences ( $p<0.05)$ among the different concentrations of glyphosate according to Duncan's tests. The different upper case letters indicate significant differences $(p<0.05)$ for each concentration of glyphosate according to independent samples $t$ tests

Total Chlorophyll $(\mu \mathrm{g} / \mathrm{g})$

\begin{tabular}{|c|c|c|c|}
\hline \multirow[t]{2}{*}{$\begin{array}{c}0.5 \text { mM SA+ } \\
\text { Glyphosate (mM) }\end{array}$} & & & \\
\hline & 1st day & 5th day & 10th day \\
\hline Control & $\mathrm{A} 13.07 \pm 0.04 \mathrm{bc}$ & $\mathrm{A} 13.01 \pm 0.04 a$ & $A 13.07 \pm 0.04 a$ \\
\hline 17 & $\mathrm{~A} 12.98 \pm 0.05 \mathrm{~cd}$ & $B 11.86 \pm 0.07 b c$ & $\mathrm{~B} 11.83 \pm 0.02 \mathrm{~b}$ \\
\hline 23 & $\mathrm{~A} 13.28 \pm 0.02 \mathrm{a}$ & B11.99 $\pm 0.04 b$ & C11.84 $\pm 0.02 b$ \\
\hline 30 & $A 13.23 \pm 0.07 a b$ & $\mathrm{~B} 11.78 \pm 0.01 \mathrm{C}$ & $\mathrm{B} 11.74 \pm 0.02 \mathrm{~b}$ \\
\hline 39 & $\mathrm{~A} 12.87 \pm 0.10 \mathrm{~d}$ & $B 11.39 \pm 0.08 d$ & B11.44 $\pm 0.03 c$ \\
\hline 51 & $\mathrm{~A} 13.06 \pm 0.06 \mathrm{bcd}$ & $B 11.50 \pm 0.03 d$ & $\mathrm{C} 11.45 \pm 0.01 \mathrm{C}$ \\
\hline 66 & $\mathrm{~A} 12.69 \pm 0.11 \mathrm{e}$ & C9.73 $\pm 0.07 \mathrm{~g}$ & $B 10.19 \pm 0.06 d$ \\
\hline 85 & $\mathrm{~A} 11.69 \pm 0.04 \mathrm{f}$ & C9.92 \pm 0.06 ef & B9.91 $\pm 0.05 e$ \\
\hline 111 & $\mathrm{~A} 11.50 \pm 0.01 \mathrm{~g}$ & $\mathrm{C} 10.01 \pm 0.03 e$ & C9.92 $\pm 0.08 \mathrm{e}$ \\
\hline 145 & $\mathrm{~A} 11.41 \pm 0.02 \mathrm{~g}$ & B9.79 $\pm 0.10 \mathrm{fg}$ & C9.62 $\pm 0.13 f$ \\
\hline
\end{tabular}

Table 9: Changes in total chlorophyll in Z. mays leaves. The different lower case letters indicate significant differences ( $<<0.05)$ among the different concentrations of glyphosate according to Duncan's tests. The different upper case letters indicate significant differences $(p<0.05)$ for each concentration of glyphosate according to independent samples $t$ tests

\begin{tabular}{|c|c|c|c|}
\hline \multicolumn{4}{|c|}{ Total Carbohydrate $(\mu \mathrm{g} / \mathrm{g})$} \\
\hline \multicolumn{4}{|l|}{$\begin{array}{c}0.5 \text { mM SA+ } \\
\text { Glyphosate (mM) }\end{array}$} \\
\hline & 1st day & 5th day & 10th day \\
\hline Control & $\mathrm{A} 0.50 \mathrm{a}$ & A0.51a & $\mathrm{A} 0.49 \mathrm{a}$ \\
\hline 17 & $\mathrm{~A} 0.53 \mathrm{a}$ & B0.47b & $\mathrm{C} 0.40 \mathrm{~b}$ \\
\hline 23 & $\mathrm{~A} 0.47 \mathrm{~b}$ & B0.40c & B0.37c \\
\hline 30 & $\mathrm{~A} 0.51 \mathrm{a}$ & B0.43bc & $\mathrm{C} 0.36 \mathrm{c}$ \\
\hline 39 & $A 0.49 b$ & B0.39c & $\mathrm{C} 0.31 \mathrm{c}$ \\
\hline 51 & $\mathrm{~A} 0.51 \mathrm{a}$ & B0.40c & $C 0.29 d$ \\
\hline 66 & $\mathrm{~A} 0.52 \mathrm{a}$ & B0.39c & C0.26d \\
\hline 85 & $\mathrm{~A} 0.50 \mathrm{a}$ & B0.36c & C0.24d \\
\hline 111 & $\mathrm{~A} 0.49 \mathrm{a}$ & $B 0.24 d$ & $\mathrm{C} 0.18 \mathrm{e}$ \\
\hline 145 & $\mathrm{~A} 0.43 \mathrm{~b}$ & B0.30d & $\mathrm{C} 0.21 \mathrm{~b}$ \\
\hline
\end{tabular}

Table 10: Changes in total carbohydrate in Z. mays leaves. The different lower case letters indicate significant differences ( $<<0.05)$ among the different concentrations of glyphosate according to Duncan's tests. The different upper case letters indicate significant differences $(p<0.05)$ for each concentration of glyphosate according to independent samples $t$ tests 
Citation: Akbulut GB, Yigit E, Bayram D (2015) Investigation of the Effects of Salicylic Acid on Some Biochemical Parameters in Zea mays to Glyphosate Herbicide. J Environ Anal Toxicol 5: 271. doi:10.4172/2161-0525.1000271

Page 7 of 9

A number of studies showed that exogenous application of SA influence the antioxidant capacity of plant. At the same time, since adaptation to oxidative stress includes not only the regulation of the synthesis and repair of proteins but also increased andioxidant activity [60]. Belkadhi et al. reported that antioxidant activity effect was improved by SA in Cd-stressed plantlets [57].

GST is a phase II enzyme that aids conjugating pollutants or/and their metabolites with glutathione favoring their further excretion [6163]. High activities of GST are usually associated with the presence of organic pollutants or pro-oxidant conditions [62]. GR is one of the potential enzymes of the enzymatic antioxidant system, which sustains the reduced status of GSH via ascorbate-glutathione pathway and plays a vital role in maintenance of sulfhydryl group and acts as a substrate for GST [64]. In our research, in the SA-treated plants GST and GR enzyme activities and total GSH content increased considerably compared to the control (Tables 5-7). This may be expressed by the fact that more ROS is occured in the plants applicated with higher dosages of the herbicide and GSH, GR and GST are formed being used as an antioxidant during the detoxification reactions with the produced ROS.

There are reports showing that MDA content increased in various plants with the effect of herbicide implementation $[65,66]$. Singh et al. reported that the oxidative damage markers lipid peroxidation (MDA) and protein oxidation products increased with doses of D2, UV-B1 and UV-B2 [23]. Lipid peroxidation was partially increased by applying SA to glyphosate maize plant (Table 8 ). The reason of this increase may be related to the induction of stress resistance by SA.

Chlorophyll is a natural pigment that absorbs light energy for photosynthesis. A greater understanding about contents of chlorophyll pigments, would be expected to yield improved methods of evaluating plant responses to the environmental stresses $[67,68]$. Baninasab and Baghbanha reported that the application of SA improved chlorophyll fluorescence ratio of cucumber (Cucumis sativus $\mathrm{L}$.) seedlings exposed to salt stress [69]. In this research, we found decrease in the total chlorophyll content compared to the control associated by applying SA to glyphosate in maize plant. The decrease may be due to the formation of proteolytic enzymes such as chlorophyllase, which is responsible for the chlorophyll degradation [70]. Probably, in our findings, decrease in the total chlorophyll may be correlated to chlorophyllase enzyme.

Carbohydrates are the direct products of photosynthetic activity and constitute a source of energy and metabolites as well as structural building blocks $[71,72]$. It was determined in our study that, in SAtreated plants, total soluble carbohydrate decreased considerably in $Z$. mays exposed to glyphosate (Table 10). Besides this, related to decrease in the total chlorophyll content.

\section{Conclusions}

In this study, it was detected that glyphosate caused toxic effect for culture plant $Z$. mays and that stress effects may be reduced by SA against the damage that may be caused by glyphosate. Besides this, POD, APX, SOD and GST, were activated by SA treatment, while others like GR, GSH, CAT were found to be inhibited. This is linked to the SA-increased level of POD, APX, SOD and GST activities under glyphosate stress. It was also determined that glyphosate affected on the MDA level, total chlorophyll and total soluble carbohydrate.

\section{Acknowledgements}

This work (Project No: BAP 2010-24) was financially supported by Inonu University.

\section{References}

1. Willy HV (2010) Soils, Plant Growth and Crop Production, Vol 2, Eolss Publishers Company Limited, Paris, France.

2. Geoffroy L, Frankart C, Eullaffroy $P$ (2004) Comparison of different physiological parameter responses in Lemna minor and Scenedesmus obliquus exposed to herbicide flumioxazin. Environmental Pollution 131: 233-241.

3. Hepel M, Stobiecka M, Peachey J, Miller J (2012) Intervention of glutathione in pre-mutagenic catechol-mediated DNA damage in the presence of copper(II) ions. Mutation Res. 2: 1-11.

4. Qaisar M, Muhammad B, Sumira J (2014) Chapter 17 - Herbicides, Pesticides, and Plant Tolerance: An Overview. Emerging Technologies and Management of Crop Stress Tolerance 1: 423-448.

5. Johal GS, Huber DM (2009) Glyphosate effects on diseases of plants. Europ J Agronomy 31: 144-152

6. Hernandez A, Garcia-Plazaola JI, Becerril JM (1999) Glyphosate effects on phenolic metabolism of nodulated soybean (Glycine max L. Merr.). J Agric Food Chem 47: 2920-2925.

7. Geiger DR, Kapitan SW, Tucci MA (1986) Glyphosate inhibits photosynthesis and allocation of carbon to starch in sugar beet leaves. Plant Physiol 82: 468472 .

8. María de N, de Felipe MR, Fernández-Pascual M (2005) Alterations induced by glyphosate on lupin photosynthetic apparatus and nodule ultrastructure and some oxygen diffusion related proteins. Plant Physiol Biochem 43: 985-996.

9. Bott S, Tesfamariam T, Candan H, Cakmak I, Römheld V, et al. (2008) Glyphosate-induced impairment of plant growth and micronutrient status in glyphosate-resistant soybean (Glycine max L.) Plant Soil 312: 185-194.

10. Boutin C, Strandberg B, Carpenter D, Mathiassen SK, Thomas PJ (2014) Herbicide impact on non-target plant reproduction: What are the toxicological and ecological implications? Environmental Pollution 185: 295-306.

11. Khan MIR, Syeed S, Nazar R, Anjum NA (2012) An insight into the role of salicylic acid and jasmonic acid in salt stress tolerance. Phytohormones and abiotic stress tolerance in plants $277-300$.

12. Alam Md M, Hasanuzzaman M, Nahar K, Fujita M (2013) Exogenous salicylic acid ameliorates short-term drought stress in mustard (Brassica juncea L.) seedlings by upregulating the antioxidant defense and glyoxalase system. Aust J Crop Sci 7: 1053-1063.

13. Hasanuzzaman M, Alam Md. M, Nahar K, Ahamed KU, Fujita M (2014) Exogenous salicylic acid alleviates salt stress-induced oxidative damage in Brassica napus by enhancing the antioxidant defense and glyoxalase systems. Australian Journal of Crop Science 8: 631-639.

14. Raskin I (1992) Salicylate, A New Plant Hormone. Plant Physiol 99: 799-803.

15. Miura K, Tada Y (2014) Regulation of water, salinity, and cold stress responses by salicylic acid. Frontiers in Plant Science 5: 1-12.

16. Hayat Q, Hayat S, Irfan M, Ahmad A (2010) Effect of exogenous salicylic acid under changing environment: A review. Environ and Exp Botany 68: 14-25.

17. Fayez KA, Bazaid SA (2014) Improving drought and salinity tolerance in barley by application of salicylic acid and potassium nitrate. Journal of the Saudi Society of Agricultural Sciences 13: 45-55.

18. Uzunova AN, Popova LP (2000) Effect of salicylic acid on leaf anatomy and chloroplast ultrastructure of barley plants. Photosynthetica 38: 243-250.

19. Vicente MRS, Plasencia J (2011) Salicylic acid beyond defence: its role in plant growth and development. Journal of Experimental Botany 1-18.

20. Wrzaczek M, Vainonen JP, Gauthier A, Overmyer K, Kangasjärvi J (2011) Reactive Oxygen in Abiotic Stress Perception - From Genes to Proteins, Abiotic Stress Response in Plants - Physiological, Biochemical and Genetic Perspectives 27-54.

21. Foyer CH, Noctor G (2003) Redox sensing and signalling associated with reactive oxygen in chloroplasts, peroxisomes and mitochondria. Physiol Plant 119: 355-364. 
Citation: Akbulut GB, Yigit E, Bayram D (2015) Investigation of the Effects of Salicylic Acid on Some Biochemical Parameters in Zea mays to Glyphosate Herbicide. J Environ Anal Toxicol 5: 271. doi:10.4172/2161-0525.1000271

22. Jiang $\mathrm{L}$, Yang $\mathrm{H}$ (2009) Prometryne-induced oxidative stress and impact on antioxidant enzymes in wheat. Ecotoxi and Environ Safety 72: 1687-1693.

23. Singh VP, Kumar J, Samiksha S, Prasad SM (2014) Dimethoate modifies enhanced UV-B effects on growth, photosynthesis and oxidative stress in mung bean (Vigna radiata L.) seedlings: Implication of salicylic acid. Pest Biochemistry and Physiol 116: 13-23.

24. Nemat Alla MM, Badawi AM, Hassan NM, El-Bastawisy ZM, Badran EG (2008) Herbicide tolerance in maize is related to increased levels of glutathione and glutathione associated enzymes. Acta Physiol Plant 30: 371-379.

25. Gangwar S, Singh VP (2011) Indole acetic acid differently changes growth and nitrogen metabolism in Pisum sativum L. seedlings under chromium (VI) phytotoxicity: implication of oxidative stress. Sci Hortic 129: 321-328.

26. Hoagland DR, Arnon DI (1938) The water culture method for growing plants without soil. California Agr Expt Sta Circ, Berkeley 347: 39.

27. Peters JL, Castillo FJ, Heath RL (1988) Alteration of extracelluar enzymes in Pinto bean leaves upon exposure to air pollutants, ozone and sulfur dioxide. Plant Physiol 89: 159-164.

28. Mac Adam, JW, Nelson CJ, Sharp RE (1992) Peroxidase activity in the lea elongation zone of tall fescue. Plant Physiol 99: 872-878.

29. Nakano Y, Asada K (1981) Hydrogen peroxide is scavenged by ascorbatespecific peroxidase in spinach chloroplasts. Plant Cell Physiol 22: 867-880

30. Cakmak I (1994) Activity of a scorbate-dependent $\mathrm{H}_{2} \mathrm{O}_{2}$-scavenging enzymes and leaf chlorosis are enhanced in magnesium-deficient and potassium deficient leaves, but not in phosphorus-deficient leaves. J Exp Bot 45: 12591266 .

31. McCord JM, Fridovich I (1969) Superoxide Dismutase: an enzymic function for erytreoeuprein (Hemoeuprein). J Biol Chem 244: 6049-6055.

32. Luck H (1963) Catalase. Methods of Enzymatic Analysis 3: 885-888.

33. Habig WH, Pabst MJ, Jakoby WB (1974) Glutathione S-Transferases: The first enzymatıc step ın mercapturıc acıd formatıon. J Biol Chem 249: 7130-7139.

34. Crib A.E., Leeder J.S., Spielberg S.P (1989) Use of a microplate reader in an assay of glutathione reductase using 5,5'-dithiobis(2-nitrobenzoic acid). Anal Biochem 183: 195-196.

35. Akerboom TPM, Sies H (1981) Assay of glutathione, glutathione disulfide and glutathione mixed disulfide in biological samples, in W.B. Jakoby (Ed.), Methods in Enzymology, Academic Press, New York 77: 373-382.

36. Heath RL, Packer L (1968) Photoperoxidation in isolated chloroplast, I. Kinetics and stoichiometry of fatty acid peroxidation. Arch Biochem Biophys 125: 180198

37. De-Kok L Graham M (1989) Levels of pigments, soluble proteins, amino acids and sulfhydryl compounds in foliar tissue of Arabidopsis thaliana during dark induced and natural senesence. Plant Physiol Bioch 27: 203-210.

38. Lichtenthaler K, Welburn AR (1983) Determination of total carotenoids and chlorophylls $a$ and $b$ of leaf extracts in different solvents. Biochem Soc T 11: 591-592.

39. Rosenberg S (1980) Physiological studies of lignocellulose degratation by thermotolerant mold Chrysosprorium prunosum. Symposium on the Biological Transformation of Lignocellulose 12: 133-142.

40. Bradford MM (1976) A rapid and sensitive for the quantitation of microgram quantitites of protein utilizing the principle of protein-dye binding. Anal Biochem 72: $248-254$

41. Duncan DB (1955) Multiple range and multiple $F$ tests biometrics. 11: 1-14

42. Beuret CJ, Zirulnik F, Giménez MS (2005) Effect of the herbicide glyphosate on liver lipoperoxidation in pregnant rats and their fetuses. Reprod Toxicol. Mar-Apr 19: 4 501-504

43. Djanaguiraman M, Annie Sheeba J, Durga Devi D, Bangarusamy U, Prasad PVV (2010) Nitrophenolates spray can alter boll abscission rate in cotton through enhanced peroxidase activity and increased ascorbate and phenolics levels. Journal of Plant Physiology 167: 1-9.
44. Radwan DEM (2012) Salicylic acid induced alleviation of oxidative stress caused by clethodim in maize (Zea mays L.) leaves. Pesticide Biochemistry and Physiology 102: 182-188.

45. Franca AC, Freitas MAM, Fialho CMT, Silva AA, Reis MR, et al. (2010) Growth of arabica coffee cultivars submitted to glyphosate doses. Planta Daninha 28 : 599-607.

46. Franca AC, Carvalho FP, Fialho CMT, D'Antonino L, Silva AA, et al. (2013) Simulated glyphosate drift on Acaiá and Catucaí coffee cultivars, Planta Daninha 31: 443-451.

47. Franca AC, Freitas MAM, D’Antonino L, Fialho CMT, Silva AA, et al. (2010) Nutrient content in arabica coffee cultivars subjected to glyphosate drift, Planta Daninha 28: 877-885.

48. Schrübbers Lars C, Valverde BE, Sørensen JC, Cedergreen N (2014) Glyphosate spray drift in Coffea arabica - Sensitivity of coffee plants and possible use of shikimic acid as a biomarker for glyphosate exposure. Pesticide Biochemistry and Physiology 115: 15-22.

49. Djanaguiraman M, Annie Sheeba J, Durga Devi D, Bangarusamy U, Prasad PVV (2010) Nitrophenolates spray can alter boll abscission rate in cotton through enhanced peroxidase activity and increased ascorbate and phenolics levels. J Plant Physiol 167: 1-9.

50. Markkola AM, Tarvainen O, Ahonen-Jonnarth U (2002) Urban polluted forest soils induce elevated root peroxidase activity in Scots Pine (Pinus sylvestris L.) seedlings. Environ Pollut 116: 273-278.

51. Cho UH, Seo NH (2005) Oxidative stress in Arabidopsis thaliana exposed to cadmium is due to hydrogen peroxide accumulation. Plant Sci 168: 113-120.

52. Wang SH, Yang ZM, Lu B, Li SQ, Lu YP (2004) Copper induced stress and antioxidative responses in roots of Brassica juncea L. Bot. Bull. Acad. Sin. 45 203-212.

53. Yamato S, Katagiri M, Ohkawa H (1994) Purification and characterization of a protoporphyrinogen-oxidizing enzyme with peroxidase activity and light dependent herbicide resistance in tobacco cultured-cells, Pestic Biochem Physiol 50: 72-82.

54. Basantani M, Srivastava A, Sen S (2011) Elevated antioxidant response and induction of tau-class glutathione S-transferase after glyphosate treatment in Vigna radiata (L.) Wilczek. Pesticide Biochemistry and Physiology 99: 111-117.

55. Rao MV, Paliyath G, Ormrod DP, Murr DP, Watkins CB (1997) Influence of salicylic acid on $\mathrm{H}_{2} \mathrm{O}_{2}$ production, oxidative stress, and $\mathrm{H}_{2} \mathrm{O}_{2}$ metabolizing enzymes (salicylic acid-mediated oxidative damage requires $\mathrm{H}_{2} \mathrm{O}_{2}$ ) Plant Physiol 115: 137-149.

56. Zhang WN, Chen WL (2011). Role of salicylic acid in alleviating photochemica damage and autophagic cell death induction of cadmium stress in Arabidopsis thaliana. Photochem Photobiol Sci 10: 947-955.

57. Belkadhi A, De Haro A, Soengas P, Obregon S, Cartea ME, et al. (2013) Salicylic acid improves root antioxidant defense system and total antioxidant capacities of flax subjected to cadmium. OMICS A Journal of Integrative Biology 17: 398-406.

58. Wang SH, Yang ZM, Lu B, Li SQ, Lu YP, et al. (2004) Copper induced stress and antioxidative responses in roots of Brassica juncea $L$ Bot Bull Acad Sin 45: 203-212.

59. Zhu Z, Wei G, Li J, Qian Q, Yu J, et al. (2004) Silicon alleviates salt stress and increases antioxidant enzymes activity in leaves of salt-stressed cucumber (Cucumis sativus L.) Plant Sci 167: 527-533.

60. Ananieva EA, Christov KN, Popova LP (2004) Exogenous treatment with salicylic acid leads to increased antioxidant capacity in leaves of barley plants exposed to paraquat. J Plant Physiol 161: 319-328.

61. Ketterer B, Meyer DJ, Clark JR (1988) Soluble glutathione transferase isozymes. In Glutathione conjugation (Eds H. Sies and B. Ketterer). Academic Press, New York.

62. Livingstone DR (2001) Contaminated-stimulated reactive oxygen species production and oxidative damage in aquatic organisms. Mar Pollut Bull 42 656-666.

63. Mena F, Fernández San Juan M, Campos B, Sánchez-Ávila J, Faria M, et al. (2014) Pesticide residue analyses and biomarker responses of native Costa Rican fish of the Poeciliidae and Cichlidae families to assess environmental impacts of pesticides in Palo Verde National Park. J Environ Biol 35: 19-27. 
Citation: Akbulut GB, Yigit E, Bayram D (2015) Investigation of the Effects of Salicylic Acid on Some Biochemical Parameters in Zea mays to Glyphosate Herbicide. J Environ Anal Toxicol 5: 271. doi:10.4172/2161-0525.1000271

64. Yousuf PY, Hakeem KUR, Chandna R, Ahmad P (2012) Role of glutathione reductase in plant abiotic stress. Abiotic Stress Responses in Plants: Metabolism, Productivity and Sustainability 149-158.

65. Lukatkin AS, Gar'kova AN, Bochkarjova AS, Nushtaeva OV, Silva JAT (2012) Treatment with the herbicide TOPIK induces oxidative stress in cereal leaves. Pestic Biochem Physiol 105: 44-49.

66. Xu J, Duan X, Yang J, Beeching JR, Zhang P (2013) Enhanced reactive oxygen species scavenging by overproduction of superoxide dismutase and catalase delays postharvest physiological deterioration of Cassava storage roots. Plant Physiology 161: 1517-1528.

67. Blackburn GA (1998) Quantifying Chlorophylls and Caroteniods at Leaf and Canopy Scales: An Evaluation of Some Hyperspectral Approaches. Remote Sensing of Environment 66: 273-285.
68. Golkar P, Arzani A, Rezaei AM, Yarali Z, Yousefi M (2009) Genetic variation of leaf antioxidants and chlorophyll content in safflower. African Journal of Agricultural Research 4: 1475-1482.

69. Baninasab B, Baghbanha MR (2013) Influence of salicylic acid pre-treatment on emergence and early seedling growth of cucumber (Cucumis sativus) under salt stress. International Journal of Plant Production 7: 187-206.

70. Sabater B, Rodriguez, MI (1978) Control of chlorophyll degradation in detached leaves of barley and oat through effect of kinetin on chlorophyllase levels. Physiol Plant 43: 274-276.

71. Kramer PJ, Kozlowski TT (1979) Physiology of Woody Plants. Academic Press London, 258-274.

72. Sivaci A (2006) Seasonal changes of total carbohydrate contents in three varieties of apple (Malus sylvestris Miller) stem cuttings. Scientia Horticulturae 109: 234-237. 